\title{
Afslutningens poetik hos Cervantes
}

\author{
RigmOR KAPPEL SCHMIDT
}

I Don Quixote er der en passage, jeg bliver ved at vende tilbage til. I slutningen af kap. XXIV, bd. II, møder don Quixote en page, der er på vej i krig. Don Quixote, der vil belære ham om det ærefulde hverv, det er at tjene Gud og kongen i krig, bagatelliserer døden ved at sige, at " ${ }^{\text {" }}{ }^{\mathrm{I}}{ }^{\mathrm{T}}$ er bare døden og så er den ikke længere". Ret beset er det et moderne syn på døden, hvor livet ophører med døden, så man ikke længere findes som en bevidsthed, der kan registrere noget $\mathrm{i}$ den anledning. Det kæder don Quixote sammen med, at man ved den uventede, pludselige og uforudsete død slipper for enhver sindsbevægelse. Døden indebærer ikke noget transcendent efterliv, men kun en jordisk reaktion, som kan undgås, hvis døden indtræffer hurtigt. Det er døden som en lakonisk afsluming uden andet transcendent efterliv end et godt ry, der er anledningen til denne artikel.

\section{Den absolutte afslutning}

Miguel de Cervantes er ofte tvetydig i sine beskrivelser. Han kan således lade en person sige ét og gøre noget andet for at vise, at en person er splittet mellem ét tankesæt og et ganske andet handlingsmønster. Når man tilsvarende kan se en splittelse omkring afslutninger, der svinger mellem at være lukkede og åbne, knytter dette spørgsmål om afslutningens poetik sig til et større, eksistentielt spørgsmål om, hvorvidt livet afsluttes med døden, eller der findes et liv i det hinsidige. Til gengæld er der en klar sammenhæng mellem menneskeliv og fortælling, idet begge forløb lægger op til en række mulige afslutninger, der tilsammen danner en afslutningens poetik.

En fortælling, der kun omhandler et udsnit af et menneskeliv, kan i princippet fremstå afsluttet, men vil altid kunne genoptages og omgøres. ${ }^{2}$ Kun hvis fortællingen omhandler menneskelivet frem til døden, er afslutningen absolut og uomgørlig. Ser man nøjere på den absolutte afslutning, vil man imidlertid opdage, at der også kredses om muligheden for, at der findes et liv efter døden. Imidlertid kan Cervantes' tvetydighed på dette felt minde om hans tvetydighed omkring personbeskrivelsen. Her tænker jeg ikke på den ambivalens, som Riley foreslår, men på en markering af to kulturelt forskellige opfattelser af døden, som efterlods sætter sig deres spor i en tilsvarende modsætningsfyldt poetik.

Galejfangen Ginés de Passamonte, som don Quixote og Sancho møder i kap. XXII, bd. I, har også sin opfattelse af forholdet mellem liv og fiktion og mellem liv og død. Han skriver på La vida de Ginés de Passamonte, en levnedsbeskrivelse, han først mener at kunne afslutte ved sin død. Parallelliteten mellem liv og fortælling danner en minimal poetik, der peger på, at kun døden er en definitiv afslutning, mens alle andre afslutninger er foreløbige og altid vil kunne genoptages. Det kunne være en poetik, der alene gælder hans egen levnedsbeskrivelse, så andre fortællinger sagtens kan have en definitiv afslutning. Ser man imidlertid på de indlejrede fortællinger i Don Quixote, optræder der en række eksempler på afslutninger, der bliver genoptaget. Passamonte formulerer således en markant poetik, der viser sig også at gælde for de andre livshistorier, der fortælles $i$ værket. Enhver afslutning, bortset fra døden, er foreløbig og vil altid kunne omgøres. Der findes således ikke aristotelisk sluttede forløb, hverken i livet eller i fiktionen, bortset fra dem, der afsluttes med døden. Denne opfattelse af døden, der endegyldigt afslutter alt og ikke følges af 'noget', kan sammenlignes med don Quixotes bemærkning om, at “det er bare dø-

Passage $49-2004$ 
den og så er den ikke længere”. Den pludselige død giver ikke plads for nogen følelsesmæssig investering fra den dødes side.

Men, kan man spørge, er Passamontes poetik nu også så central i et værk, hvor kritikken ofte sætter fokus enten på Cide Hamete Benengeli og hans metafiktionelle funktion i værket eller på præstens og kannikkens poetologiske diskussion om de aristoteliske forskrifter. Passamontes poetik er interessant af to grunde. Den forholder sig til, at bortset fra døden kan enhver afslutning tages op igen og omgøres, hvilket netop sker i praksis i mange af de indlejrede fortællinger. Desuden optræder Passamonte igen i kap. XXV-XXVI, bd. II som maese Pedro, hvor han igennem sin mesterjakelopførelse sammen med don Quixote dramatiserer en brydning mellem implicit og eksplicit fortællekonstruktion. Maese Pedro trækker i bogstavelig forstand i trådene bag scenen uden at lægge stemme til fortællingen. Han indtager således den 'implicitte' position bag scenen. Når jeg skriver implicit i anførselstegn, skyldes det, at implicitheden gøres eksplicit ved at maese Pedro iscenesætter sig selv som implicit dukkefører, men også ved at don Quixotes indgriben tvinger ham til at gribe eksplicit ind, hvilket efterlods gør os opmærksom på maese Pedros tidligere 'implicitte' optræden. (Den iscenesatte 'implicithed' kan i øvrigt betragtes som en forudskikkelse af den skjulte fortælleposition, der senere viste sig at vokse frem $i$ europæisk romankunst). Den eksplicitte fortællestemme besørges af knægten foran scenen. I forhold til teatrets fordeling af funktionerne forventes tilskuerne at optræde ligesom senere tiders diskrete, implicitte læsere, der ikke blander sig i handlingsgangen. Don Quixote kan imidlertid ikke forholde sig $\mathrm{i}$ ro og griber ind $\mathrm{i}$ handlingen. Det sker forst med ord, hvad der tvinger maese Pedro til at tale don Quixote efter munden, men se om det hjælper, for snart griber don Quixote til sværdet og afliver maese Pedros trup af marionetdukker. Hermed fjerner don Quixote ikke kun enhver mulighed for videre handling, men ødelægger også maese Pedros eksistensgrundlag.

Passamonte repræsenterer en usentimental, lavsocial poetik, der er nøgtern i forhold til livets om- skiftelser og rummer en grundlæggende accept af døden som livets afslutning. Pragmatisk sørger han for at få det bedste ud af don Quixotes massakre på marionetteatret, selv om det umiddelbart virker som en total tilintetgørelse af hans fremtidsmuligheder. Stillet over for partielle afslutninger lader Cervantes således ofte sine personer søge en udvej ud af kniben, så den tilsyneladende tilintetgørende afslutning omgøres med henblik på et mere lyst og forsorent livsperspektiv. Det sker ikke kun i hans fortællinger, men også $\mathrm{i}$ hans egen biografi. Her får han vendt helt umulige situationer og fundet løsninger, hvor de fleste andre $\mathrm{i}$ hans samtid ville være blevet hængt eller fået så mange stokkeprygl, at de næppe havde overlevet det.

\section{Et evigt liv efter døden?}

I kap. XII, bd. II drager don Quixote en parallel mellem la comedia og livet. Hver især tildeles en rolle, og når comedia'en er færdig, tager skuespillerne deres dragter af og er ikke længere forskellige typer. Det samme sker med menneskene, der livet igennem indtager hver deres plads i livet, men alle bliver ens i graven. Her tydeliggør don Quixote, at livet karakteriseres af forskelle, mens døden er forskelsløs. I forhold til jordelivet, der er karakteriseret ved forskelle, præsenteres man i Don Quixote for, at døden ophæver de selvsamme forskelle. Når døden er forskelsløs, kan man ikke sige, at der er 'noget' efter døden, idet 'noget' forudsætter eksistensen af 'noget andet'.

Det store spørgsmål bliver nu, om døden markerer en afslutning? Kendt er selvfølgelig eksemplet med den mirakuløse balsam, der kan redde ridderen, selv hvis han er blevet hugget over i to dele (kap. $\mathrm{X}$, bd. I). Men hvad med den mere realistiske død i Don Quixote? Fører den over i noget nyt eller indebærer den en egentlig afsluming?

"[...] og således går tiden bestandig $\mathrm{i}$ denne fortsatte ring. Kun menneskelivet går mod sin afslutning på lettere fjed end tiden, og det har forst håb om fornyelse i det andet liv, der ikke begranses af afslutninger." Det siger Cide Hamete, muhammedansk filosof: og salledes har mange forstået det nuvarende livs ubetydelighed og flygtighed og det 
evige livs varighed, selv om de ikke har set troens lys, men har indset det ved naturens lys. Her siger vores forfatter det dog kun, fordi Sanchos regentskab så hurtigt nåede sin afslutning, kom til en ende, opløstes og forsvandt som i skygger og røg (kap. LIII, bd. II). ${ }^{3}$

Indtil nu har vi set døden som en absolut afslutning på livet, men med dette citat viser livet sig ganske vist stadig at have en afslutning $i$ døden, men bliver nu fulgt af et andet liv efter døden. Det ekspliciteres ikke her, hvori det evige liv består. Man kan derfor formode, at også når Cervantes opererer med et liv efter døden, er der tale om et forskelsløst liv, hvor der ikke findes afslutninger, intet skifte fra en tilstand til en anden, ja, end ikke de delvise afslutninger, der præger jordelivet. Tænker man nøjere efter, er det døden som afslutning, der skaber forskelle i jordelivet, også udtrykt ved at vi hver især spiller vores roller i livet som teater. Det andet liv, der $\mathrm{i}$ øvrigt stadig kun præsenteres som en mulighed, begrænses ikke af afslutninger, men hvis der ikke er afslutninger, opstår der heller ikke forskelle. Igen kan man kun slutte ud fra jordelivet, hvor eksempelvis Sancho $\mathrm{i}$ en periode er guvernør og derefter ophører med at være det for at blive noget andet.

Det er ikke kun døden som sådan, men også de partielle afslutninger undervejs $\mathrm{i}$ jordelivet, der er med til at indsætte de forskelle, der præger jordelivet til forskel fra livet efter døden. Så hvad enten det hinsidige findes eller ej, vil det være forskelsløst, simpelthen fordi der ikke er afsluminger. Anderledes forholder det sig i jordelivet. Her kan man med don Quixote sige: "Hvor der lukkes en dør, åbner en anden sig" (kap. XXI, bd. I), ${ }^{4} \mathrm{i}$ betydningen: Fortvivl ikke, for noget andet vil vise sig. De åbne og lukkede døre i Don Quixote handler som regel om at finde et remedio, en udvej ud af den knibe, man er sat i. Det gør man ved at åbne den samme eller en anden dør, da den lukkede dør betyder døden. Det sidste ser man i den indlejrede novelle, Den formastelige nysgerrige, hvor Anselmo beder om at få lukket døren, ${ }^{5}$ hvorefter han nedskriver sin historie og dør. Her fører den lukkede dør ham lukt i døden. Det danner en parallel til Passamonte, der også har tænkt sig at lade fortællingens og livets ophør gå hånd $\mathrm{i}$ hånd. Døren, der endegyldigt lukker sig, og døren, som døden ${ }^{6}$ banker på, er knyttet til afslutningen såvel på livet og som på livets fortælling.

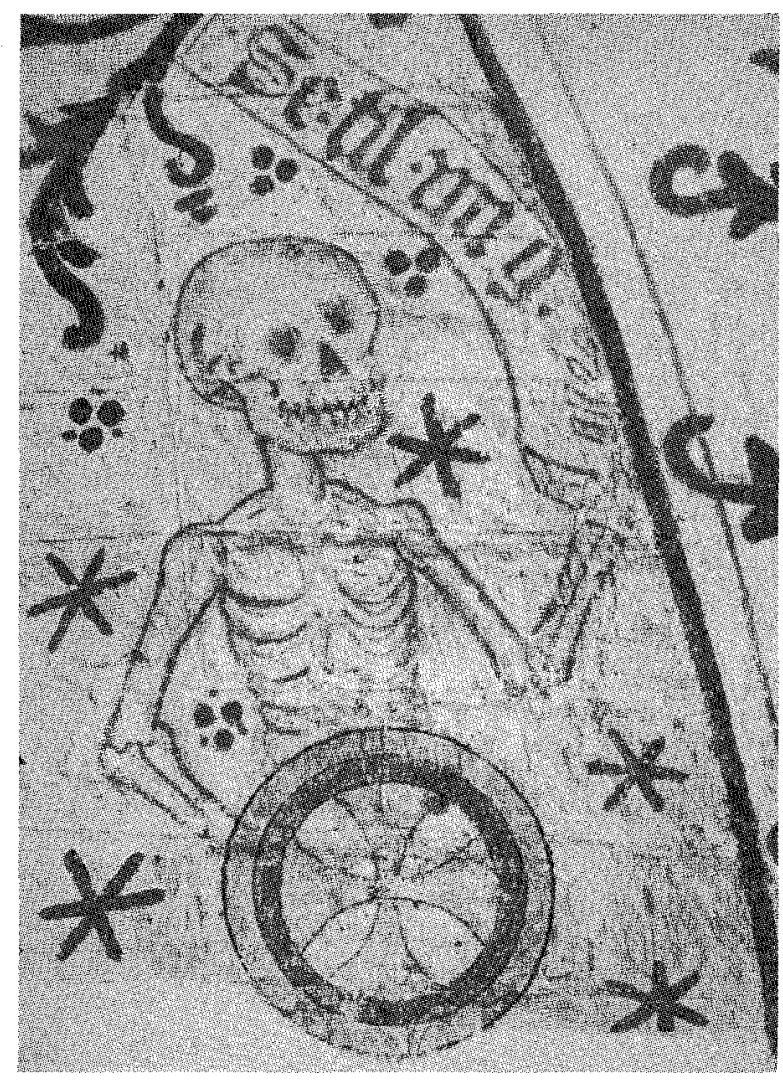

SE TIL MIG, Vigersted kirke, ca. I450

\section{Erkendelse gennem troen eller naturen?}

Lad mig lige minde om en stump af citatet fra for. "Det siger Cide Hamete, muhammedansk filosof: og således har mange forstået det nuværende livs ubetydelighed og flygtighed og det evige livs varighed, selv om de ikke har set troens lys, men har indset det ved naturens lys". Det korte jordeliv og det evige andet liv kan man fă indsigt $\mathrm{i}$ ad to veje. Den ene går gennem troen, den anden er en erkendelse, man bibringes af naturen. Religionen og naturen bliver således to parallelle veje til erkendelse. Vender vi tilbage til episoden med galejfangen Passamonte, erklærer don Quixote, at han ikke kan acceptere "at slavebinde ${ }^{7}$ mennesker, som Gud og naturen skabte 
frie" (kap. XXII, bd. I). Her kan man bemærke, at don Quixote lader Gud og naturen op rade som sideordnede skabere af mennesket. På den tid kunne man ikke tillade sig at underkende Gud, så ville man have andre drivkræfter ind, måtte man arbejde sig vej frem gennem sideordningen.

Så selv om Gud bliver næunt en del gange i Don Quixote, er der alligevel en række formuleringer, der trænger sig på og kræver en forklaring. Der er døden, som en afslutning, slet og ret. Der er det andet liv, der tilsyneladende er forskelsløst, mens det dennesidige liv er præget af forskelle, der opstår af delvise afslutninger og dødens absolutte afsluming. Der er omtaler af naturfilosofferne, og endelig er der sideordnede omtaler af Gud og naturen som ligeværdige skabere. Desuden præsenteres naturen som en ganske udmærket vej til erkendelse, der sagtens kan måle sig med Gud og troen.

Den spanske cervantist Américo Castro ${ }^{8}$ kredser om, at Cervantes må have været påvirket af renæssancens naturfilosofi, men selv om Américo Castro hælder til neoplatonisme, panteisme og estoicisme, kan han ikke afgøre det med sikkerhed. Naturfilosofien bliver nævnt, idéen om naturen som en bog, der skal studeres omtales, naturen er Guds hushovmester og skaber menneskene med laster og dyder, der bliver bestemmende for deres liv. Américo Castro (s. I64) mener således, at Cervantes har en deterministisk opfattelse af naturens indflydelse på mennesket. I stedet for at lade det blive ved en vag idé om neoplatonisme og naturfilosofi, introducerer jeg $\mathrm{i}$ det følgende Averroes for at se, om Cervantes måske har ladet sig påvirke af hans ideer, der førte til naturfilosofien i dens mange varianter.

\section{Averroes}

Jeg har tidligere været inde på Averroes, ${ }^{9}$ der levede i de sidste rester af det islamiske rige Al Andalus på den Iberiske Halvø. Averroes eller Ibn Rushd, der blev født i Córdoba i 1126 og døde i Marokko i iı98, udviklede en rationel og videnskabelig islamisme med afsæt i Aristoteles' værker. Averroes har sandsynligvis udbredt sin tænkning mundtligt $i$ eller ved moskeen, som man havde for skik på den tid. Hans tanker vandt stort set ingen genklang $i$ den arabiske verden, men blev nedskrevet og oversat til hebræisk og latin. Desuden foreslår Francisco Márquez Villanueva, ${ }^{10}$ at der i den spanske middelalder udviklede sig en levende, mundtligt formidlet tradition for naturfilosofi, som udsprang af Averroes' fortolkninger af Aristoteles. Den averroistiske skelnen mellem filosofi og religion blev formidlet på den Iberiske Halvø som en mundtlig overlevering og nord for Pyrenæerne som en skriftlærd tilegnelse, der nød godt af det store arbejde, der blev udfort af oversætterskolen i Toledo. Således peger Márquez Villanueva ${ }^{11}$ på det paradoks, 'at de kastilianske præster tog nordpå for at tilegne sig latin, mens lærde drog til Toledo fra andre dele af Europa for at tilegne sig den græsk-arabiske kulturarv på det nye tholetanske sprog, kastiliansk. Det har selvfølgelig undret $\mathrm{fx}$ Juan Riera Palmero, ${ }^{\mathrm{I} 2}$ at kastilianerne tilsyneladende ikke var interesserede $i$ selv at tilegne sig de mange oversættelser, der blev udarbejdet i Toledo, men det kan forklares med, at de ikke var i stand til at læse komplicerede tekster på latin, og at de gennem mundtlig formidling modtog den tradition, som blev eksporteret ud af halvøen i bindstærke oversættelser. Man kan altså formode, at der i de Spanske Riger har været en levende tradition for naturfilosofi, der bl.a. havde sin oprindelse i Averroes' kommentarer til Aristoteles.

Den franske orientalist og religionshistoriker Ernest Renan ${ }^{13}$ har i sit banebrydende værk Averroès et l'averroïsme fra 1852 givet en præsentation af Averroes, hvori han betoner dennes rationalisme og fremhæver, at han var langt forud for sin kristne og jødiske samtid. Averroes har næppe kunnet græsk eller har haft et beskedent kendskab til græsk, men har i sit arbejde med Aristoteles' tekster sandsynligvis brugt arabiske oversættelser af syriske oversættelser af de græske tekster. Tilsvarende er der kun få arabiske håndskrifter overleveret af Averroes' kommentarer til Aristoteles. Derfor bygger kendskabet til Averroes på arabiske tekster, skrevet med hebræisk skrift, samt på de talrige oversættelser først til hebræisk og fra I480 til I580 i rigt mål også til latin. Det var i den periode, man med Eckhard Keßler ${ }^{\mathrm{I}}$ kan pege på, at averroismen bidrog til, at naturfilosofien udviklede sig til starten på den moderne 
naturvidenskab. Averroes udførte tre slags kommentarer til Aristoteles. Den store kommentar, hvor Aristoteles' tekst citeres i sin helhed afsnit for afsnit, fulgt af Averroes' kommentarer. Mellemkommentaren citerer kun begyndelsen, hvorefter resten forklares, så Averroes og Aristoteles flyder sammen. Endelig er der parafrasen, hvor Averroes taler i eget navn. Selv om Averroes med et sådant værk kunne fremstå som blot og bar kommentator, mener Renan (s. 83) tværtimod, at han tænker frit, når han tolker Aristoteles.

Averroes skelner mellem det aktive og det passive intellekt. Det aktive intellekt findes transcendent, uden for mennesket som et potentiale, men skal ikke identificeres med Gud. Når det knyttes til mennesket, går det fra at være potentielt til at blive aktualiseret. ${ }^{\text {Is }}$ I denne proces opstår det materielle intellekt som en forbindelse mellem det aktive intellekt og den tilsvarende evne i mennesket til at modtage det. Det materielle intellekt hører til de passive evner og skal derfor skelnes fra det aktive intellekt. Menneskets passive intellekt stræber efter at forene sig med det aktive intellekt, hvilket kunne opfattes som en parallel til religionens mystik, hvor sjælen stræber efter unio mystica med Gud. Averroes er imidlertid ikke særlig mystisk, men hævder tværtimod, at foreningen nås gennem viden. Eller man kunne med Renan betragte det som en rationalistisk mystik, hvor individets intellekt stræber efter at forenes med fornuften, der er et kosmisk princip. Det individuelle eller materielle intellekt er bundet til kroppen og kan ikke eksistere uden den. Når kroppen dør, forgår intellektet med den. Kun det aktive intellekt, der er lig med fornuften, er udødeligt og uforgængeligt. Averroes forestiller sig altså ikke, at der findes nogen personlig, individuel udødelighed, ${ }^{16}$ hvor menneskets sjæl på en eller anden måde fortsætter med at eksistere efter døden.

Averroes er fritænker og har ikke nogen bestemt religion i tankerne, når han filosoferer over relationen mellem religion og filosofi. Han forholder sig kritisk til skabelsen og undrer sig over, at nogen kan tro på noget så absurd. Det må skyldes vanen, idet folk tror det, de făr gentaget uafbrudt. Så hvis folk begynder at studere de spekulative videnskaber, mister de straks troen, der er baseret på vanen. Averroes mener ikke, man skal oplyse folket og fratage dem deres tro. Tværtimod skal man gøre sig klart, at engle og profeter, åbenbaring og religion er for folket, mens filosofi, der er det højeste, man kan tænke sig, er forbeholdt de fả. Vil man virkelig dyrke Gud, må man derfor søge sandheden og studere hans værk i dets fysiske realitet. Averroes lagde således afgørende vægt på naturiagttagelse og på empirisk verifikation. ${ }^{17} \mathrm{Han}$ satte fysikken over metafysikken, så selv Guds eksistens skulle bevises fysisk, ligesom kosmos anses for at have en kausal struktur og orden.

Kaster man enhver vanetænkning af sig og begynder at tænke og tilegne sig viden, kan man måske nå frem til en slags identifikation med det rationelle eller aktive intellekt. De arabiske og jødiske filosoffer og videnskabsfolk, der forholdt sig frit til de religiøse dogmer og $\mathrm{i}$ stedet interesserede sig for at forstå og erkende verden, som den forelå, fik let ry for at være materialister, livsnydere, måske endda libertinere og kættere, uden nødvendigvis at være det. Jøderne tog Averroes' privilegering af filosofi og logik til sig og anvendte den ifølge Daniel J. Lasker ${ }^{18}$ til at bevise den jødiske tros overlegenhed $i$ forhold til den kristne. Ingen af parterne anfægtede de jødiske mirakler, mens jøderne brugte Averroes til at betvivle de kristnes mirakler i en argumentation for, at den kristne tro var den jødiske underlegen. Men havde man først åbnet denne diskussion, kunne argumenterne bruges mod enhver religion, således at alle former for mirakler og naturstridige hændelser blev betragtet som umulige. I forhold til en verdensanskuelse baseret på logik, fornuft og naturlove stod enhver religion for skud. Men hvis religionerne blev mindreværdige, kunne det forekomme ligegyldigt, hvilken religion man tilsluttede sig. Sådanne tendenser inden for averroismen kunne ifølge Lasker forklare, hvorfor mange jøder valgte at omvende sig til kristendommen eller begyndte at leve hedonistisk.

\section{Rationalisme eller mirakeltro}

Udviklingen fra Averroes til naturfilosofien var båret frem af maurere og jøder, selvfølgelig ikke de jævne 
maurere og jøder, men de intellektuelle iblandt dem. For det var jo netop, hvad Averroes forudseende belærte om. Man skal drage en klar skillelinje mellem det, som intellektuelle kan spekulere over, og det, som det jævne folk kan tåle at høre. De intellektuelle maurere og jøder, der tog Averroes' tankegang til sig, blev rationalistiske, analytiske, observerende og tilbøjelige til kun at acceptere, hvad de kunne se og iagttage med deres sanser. Til gengæld byggede de kristnes verdensopfattelse på troen, hvor man accepterede undere, der ikke svarede til en rationel forståelse af verden. Denne tro skulle deles af høj som lav, intellektuel som enfoldig.

I den indlejrede novelle Den formastelige nysgerrige optræder der en interessant sammenligning mellem kristne og maurere:

Det forekommer mig, kære Anselmo, at du lige nu har åndsevner som maurerne, som man ikke kan fă til at begribe, at deres lære tager fejl, hverken med citater fra den Hellige Skrift eller gennem forstandens overvejelser, heller ikke selv om de grunder sig på trosartiklerne; tværtimod er man nødt til at bringe dem håndgribelige, letfattelige, forståelige, anskuelige, ubetvivlelige eksempler med matematiske bevisførelser, der ikke kan benægtes, som når nogen siger: 'Hvis man fra to lige lange sider fjerner to lige lange stykker, vil de tilbageblevne sider stadig være lige lange.' Og når de ikke forstår det med ord, hvad de vitterlig ikke gør, må man vise dem det med hænderne og anbringe det for øjnene af dem, og alligevel kan ingen overbevise dem om vores hellige religions sandheder. $\mathrm{Og}$ den selv samme forklaring og fremgangsmåde må jeg bruge $i$ dit tilfælde, for det ønske, der er opstået i dig, er helt forkert og $\mathrm{i}$ dén grad uden for alt, hvad der rummer den mindste smule fornuft, at jeg finder den tid spildt, som jeg bruger på at fă dig til at indse din egen enfoldighed, som jeg lige nu ikke vil benævne på anden vis, og endda er jeg som straf for dit slette ønske tilbøjelig til at lade dig forblive i din vankundighed, men det venskab, jeg nærer til dig, tillader mig ikke at være ubønhørlig og så åbenlyst at udsætte dig for at fortabes. (kap. XXXIII, bd. I). ${ }^{\text {I9 }}$

Situationen er her, at Anselmo vil anstille et forsøg for at finde ud af, om hans kone Camila er så ærbar og kysk, som hun fremstår. Han vil ikke bare tro, at hun er det. Han vil efterprøve det eksperimentelt, så han får viden om det. Planen går i al sin enkelhed ud på, at hans ven Lotario skal prøve at forføre Camila, og hvis hun holder stand, er det dermed bevist, at hun er ærbar. Lotario prøver at argumentere imod hans projekt, som han sammenligner med maurernes rationalistiske tilgang til verden. Lotarios sammenligning viser, at Cervantes har kendt til, at maurerne blev opfattet som rationalistiske og naturvidenskabelige. Umiddelbart kunne man læse passagen sådan, at maurernes rationalistiske og naturvidenskabelige indstilling afvises som gal i forhold til den kristne tro på mirakler, som ingen kan se eller verificere. Men Anselmos ønske om at anstille forsøg med sin kone er galt af en helt anden grund, nemlig at det er almindeligt kendt, at kvinder er skrøbelige som glas, så de ikke vil kunne stå en sådan prøve igennem. Citatet siger $\mathrm{i}$ virkeligheden, at Anselmo gør klogest $\mathrm{i}$ at opføre sig som de kristne, der tror på mirakler og ikke giver sig til at efterprøve dem eksperimentelt, for hvis de gjorde det, ville de ligesom averroisterne opdage, at miraklerne ikke har hold i virkeligheden. Eksemplet viser således den averroistiske dobbelthed, der siger, at kun hvis man er parat til at leve uden mirakler, skal man give sig til at efterprøve dem eksperimentelt. Og tilsvarende med konen. Eftersom man ved, at kvinder er skrøbelige som glas, er man dum eller gal, hvis man giver sig til at undersøge det nærmere, især hvis man ikke kan leve uden konen. For selvfølgelig kan Camila heller ikke klare prøven. Forfølger man Lotarios sammenligning, indebærer det desuden, at heller ikke de krisme dogmer ville kunne klare en efterprøvning. Omend det ikke bliver sagt direkte, viser Cervantes her et udmærket kendskab til forskellen mellem maurernes forkærlighed for rationalistisk, naturvidenskabelig eksperimenteren og de krismes tro på mirakler, der ikke kan eftervises.

\section{Udødelighed}

Hvis Cervantes ikke tror på de krisme mirakler, men betragter dem som dogmer, man gør klogest $i$ ikke at pille ved, ${ }^{20}$ er det sandsynligt, at han heller ikke wor på udødeligheden, men følger averroismens idé om, at den individuelle sjæl er bundet til 
kroppen og må forgå med den. Hvor den kristne religion og den folkelige islam lover den individuelle sjæl udødelighed, foreslår den averroistiske version af islam, at den individuelle, kropsbundne sjæl dør med kroppen og derfor ikke deltager i det aktive intellekts udødelighed og uforgængelighed. Det isolerer eller begrænser mennesket til en eksistens på jorden uden mulighed for et transcendent efterliv $i$ himlen.

Cervantes omtaler gerne udødelighed, blot er der ikke tale om den udødelighed, som religionerne kan love mennesket. I stedet kædes udødeligheden sammen med la fama, ryet, der dels kan brede sig geografisk i rum, dels kan få en tidslig udstrækning, der går mod uendelig. Således har Cervantes tilsyneladende taget konsekvensen af, at mennesket ikke kan deltage $i$ et transcendent efterliv og lader $i$ stedet sine personer søge udødeligheden sekulært $\mathrm{i}$ folks erindring. Hvis man vinder fama og bliver genstand for mundtlig eller skriftlig fortælling, bliver man erindret evigt og vinder dermed en slags udødelighed i denne verden. Dog åbnes der også op for, at ryet kan brede sig til himlen, hvis man er en god, kristen ridder. Cervantes lover dermed ikke nogen udødelighed for den individuelle sjæl, men nok, at ens bedrifter bliver indskrevet og husket. Det sker samtidig med, at han indfører en afslutning på den jordiske verden:

Alle disse og andre store og forskelligartede bedrifter udføres, udførtes og vil blive udført for at opnå det ry, som de dødelige ønsker som præmie og andel af den udødelighed, de med deres navnkundige gerninger gør sig fortjent til, skønt vi kristne, katolske og farende riddere mest skal tænke på de kommende århundreder og vinde evig ære i de overjordiske og himmelske sfærer, mens vi ikke skal tage os af det forfængelige ry, man kan opnå i det nuværende og forgængelige århundrede; for hvor længe dette ry end varer, vil det endeligt ophøre med denne verden, hvis afslutning er udpeget (kap. VIII, bd. II). ${ }^{2 \mathbf{I}}$

Hvor det evige ry og udødeligheden normalt er begrænset til den jordiske verden, åbnes der i netop dette citat en sprække for, at ryet også kan overføres til den himmelske verden. Imidlertid optræder hen himmelske udødelighed netop $i$ en passage, hvor don Quixote er hårdt trængt af Sancho, der prøver at overtale ham til fredeligere veje til berømmelse end ridderskabet, så don Quixote har brug for meget overbevisende argumenter.

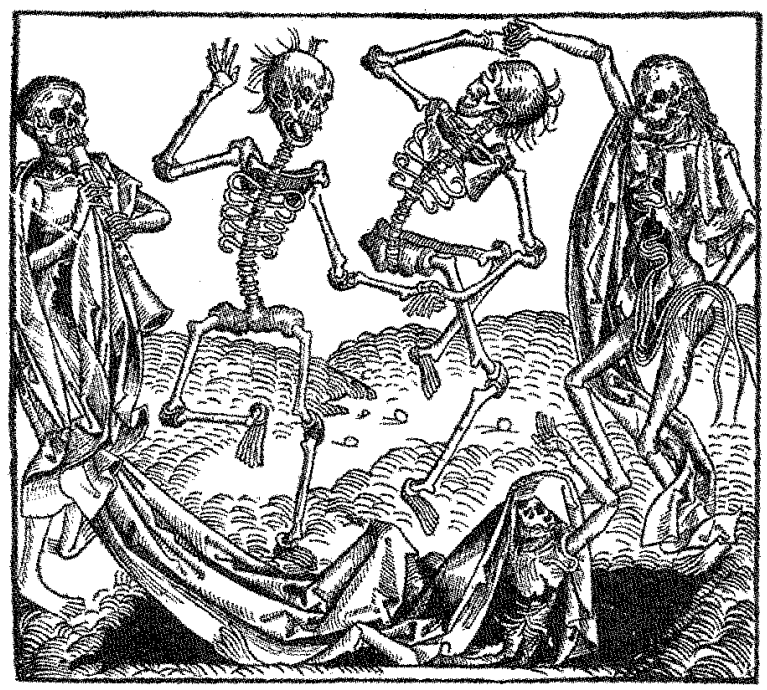

DøDedans, Michael Wolgemut, I493

\section{Afslutninger}

Fortællinger i Don Quixote er blevet afsluttet, blot for at blive taget op igen, hvis ikke afslutningerne har været lykkelige. Kun når menneskelivet har nået sin afslutning med døden, har den tilsvarende fortælling kunnet nå sin endelige afslutning. Hvis Cervantes havde troet på et liv efter døden, ville døden ikke stå som en egentlig afslutning på menneskelivet i en parallel til fortællingens afslutning. Så når han lader Passamonte regne døden som en endelig afslutning, kunne det tyde på, at han ikke har de store forventninger om et liv efter døden.

Generelt sagt udtrykker Cervantes sig 'politisk korrekt' i forhold til sin samtid, men man kan dog ind imellem studse over bemærkninger, der peger på en helt anden opfattelse. Således kan pludselige, markante bemærkninger tyde på, at Cervantes opererer inden for averroismens dobbelte system, hvor religion og mirakeltro er for folket, mens rationalisme og eksperimenter er for dem, der kan bære at få deres barnetro ødelagt. Det kan imidlertid ikke bevises, men kun sandsynliggøres, at Cervantes her forholder sig til den averroisme, der udviklede sig 
blandt intellektuelle maurere og jøder på den Iberiske Halvø. Hans personlige udgave af averroismen kan hænge sammen med hans opfattelse af livet efter døden som forskelsløst $\mathrm{i}$ forhold til jordelivet, der er præget af forskelle, som dels sættes af de partielle, omgørlige afslutninger, dels af dødens uomgørlige afslutning. På den baggrund kan det være interessant at spørge til afslutningen på Don Quixote. Men først skal jeg lige se på afslutningen af Novelas exemplares.

I Novelas exemplares er den sidste, uafsluttede fortælling Coloquio de los perros indlejret i en narrativ ramme, således at både Novelas exemplares og Coloquio afsluttes ved at rammen forlades ${ }^{22}$ og står tom tilbage: "Og hermed gik de". Den narrative ramme, der forlades, ville jeg sammenligne med scenen, der bliver forladt, når skuespillet eller jordelivet ophører. For så vidt kan den lakoniske afslutning i Novelas examplares, hvor rammen slet og ret forlades, minde om afslutningen på Don Quixote, omend slutningen på Don Quixote er lidt mere elaboreret.

Don Quixote forlader sin gale tro på, at han er don Quixote, for igen at blive Alonso Quixano. Den gale indbildning, der satte i gang kort efter starten på bd. I, udgør grundlaget for fortællingen om don Quixote. Så da han forlader denne indbildning hen mod slutningen af værket, er hele grundlaget for fortællingen dermed væk. Den korte stump tekst i start og slut, hvor han lever $\mathrm{i}$ bevidstheden om at være Alonso Quixano, kan betragtes som en spinkel ramme om fortællingen. Kort efter at han igen er blevet den gode Alonso Quixano, forlader han både ramme og jordeliv, hvorved hele beretningen ophører. I den afsluttende ramme går dødsprocessen i gang, hvilket omfatter den sidste olie, at skrive testamente, selve dødskampen, en notarbevidnet død og en begravelse, idet det betones, at kroppen går til i jorden. Hvor vi i vore dage ville henvise til en læge for at understrege, at kroppen virkelig er død, er det i datidens bureaukratiske kontekst nok så væsentligt at få døden juridisk stadfæstet af en notar. I denne sammenhæng skærpes naturlovene til dødens love for at understrege, at don Quixote ikke kan genopstå. Her skrives der fra en position, som ikke tror på en genopstandelse fra de døde og altså heller ikke på de kristne mirakler. Don Quixote har således forladt både indbildningens fiktive rum og virkelighedens realistiske rum og kan nu ikke længere genoplives. Til gengæld skrives der fra en position, som tror på fortællingen og dens evne til at vække til live. Det er den genopstandelse, det gælder om at blokere. I dødens alvorsstund pjankes der derfor ikke længere med udødelighed eller evigt ry, ligesom der trækkes på den averroistiske rationalisme for virkelig at få manet don Quixote i jorden. Således ligger det forfatteren på sinde, at man skal respektere, at don Quixote er død, og ikke forsøge at vække ham til live igen, for den, der måtte gøre det, ville rane ham fra Cervantes og dermed fratage Cervantes det evige ry, han håber at opnå på denne jord med Den sindrige ridder don Quixote de la Mancha.

Ligesom don Quixote værdigt besørgede alt inden sin død, således valgte også Miguel de Cervantes at tage afsked med livet, der for ham bestod af de fortællinger, han stadig manglede at nedfælde på papir. Efter afslutningen af Don Quixote nåede han at skrive endnu et stort værk: Los trabajos de Persiles $y$ Sigismunda, hvor han både i prologen og i dedikationen tager afsked med livet. Den første afsked optræder i prologen, der muligvis er skrevet som en fiktion om den 'døende Cervantes'. Som en effektfuld afslutming på sin artikel om afslutninger bringer Riley et citat herfra, der viser Cervantes' afsked med vennerne og med fortællekunsten:

Den tid $^{23}$ vil måske komme, hvor jeg vil genoptage den brudte tråd og sige det, jeg her mangler og det, jeg ved, der var passende. Farvel, fornøjeligheder; farvel, lystigheder; farvel, muntre venner; for jeg er ved at dø og ønsker bare at gense jer glade om føje tid i det andet liv

Som citatet står, læser man det uvilkårligt, som om Cervantes ror på et liv efter døden, hvor han vil mødes med vennerne igen, for Riley minder os ikke om det lille quizá (måske), der skaber tvivl om, hvorvidt det er muligt at anudar el hilo (genoptage tråden). Cervantes' afsked udtrykker en vis fortrydelse ved at måtte forlade vennernes muntre lag, men selv om han kunne ønske at mødes med dem i det andet liv og gerne ville fortælle videre, kædes 
det altså sammen med et lille, forbeholdent måske.

Da Persiles er helt færdig og har "foden i stigbøjlen", skriver Cervantes dedikationen med endnu en sidste afsked med livet, we dage før sin død:

Hvis himlen til min store lykke (hvad der ikke ville være lykke, men mirakel) ${ }^{24}$ tilfældigvis skulle lade mig leve

Selvfølgelig mærker man her en vældig lyst til at leve, men også en accept af dødens uafvendelighed. Så ligesom Passamonte, der regnede med at skrive sig ind i døden, og ligesom Anselmo, der skrev til pennen faldt ham af hånden og han sank død om, og ligesom don Quixote, der dikterede sit testamente og sidste vilje, hvorefter han begav sig ud $\mathrm{i}$ dødskampen, således også Miguel de Cervantes, der ledsagede sin egen død på skrift, først med en prolog, der fiktivt fremskrev ham selv som døende, derefter i en dedikation, hvor han præsenterede sig selv som døende, med mindre der indtraf et af de mirakler, han næppe kunne tro på. Og ligesom don Quixote døde tre dage efter, at han havde gjort testamente, døde også Miguel de Cervantes tre dage efter, at han havde sat sidste punktum i den dedikation, hvormed han sendte Los trabajos de Persiles y Sigismunda ud i verden.

\section{Noter}

x. "todo es morir y acabóse la obra," (kap. XXIV, bd. II).

2. Edward T. Riley har i artiklen "Cómo se termina un relato: los finales de las novelas ejemplares" (Actas del $\mathrm{X}$ Congreso de la Asociación Internacional de Hispanistas, ed. Antonio Vilanova, Barcelona 1989) foreslået, at Cervantes i Novelas exemplares bruger tre slags afsluminger, åbne, lukkede og ambivalente. Flertallet af fortællingerne er romances, hvor afslutningerne er lukkede. I hans optik ville det også gælde mange af de indlejrede fortællinger i Don Quixote, hvor jeg til gengæld vil mene, at afslutningerne faktisk genoptages og omgøres.

3. y así torna a andarse el tiempo con esta rueda continua. Sola la vida humana corre a su fin, ligera más que el tiempo, sin esperar renovarse, sino es en la otra que no tiene términos que la limiten. Esto dice Cide Hamete, filósofo mahomético; porque esto de entender la ligereza e instabilidad de la vida presente y la duración de la eterna que se espera, muchos sin lumbre de fe, sino con la luz natural, lo han entendido. Pero aquí nuestro autor lo dice por la presteza con que se acabó, se consumió, se deshizo, se fue como en sombra y humo el gobierno de Sancho. (kap. LIII, bd. II).

4. "Paréceme, Sancho, que no hay refrán que no sea verdadero, porque todos son sentencias sacadas de la misma experiencia, madre de las ciencias todas, especialmente aquel que dice: "donde una puerta se cierra, otra se abre.” (kap. XXI, bd. I). Andetsteds lader don Quixote fortrøstningsfuldt døren åbne sig midt i ulykkerne: “'Siempre deja la ventura una puerta abierta en las desdichas para dar remedio a ellas', dijo don Quijote" (kap. XV, bd.I). Og selv når alle døre lukker sig, vil man kunne finde sammen om at begræde ulykkerne - og fornøje sig med at fortælle historien om dem: "Y cuando vuestra desventura fuera de aquellas que tienen cerradas las puertas a todo género de consuelo" (kap. XXIV, bd. I).

5. "le cerrasen la puerta" (kap. XXXV, bd. I). Américo Castro peger på, at Cervantes systematisk tager livet af folk, der har optrådt tåbeligt. Américo Castro: El pensamiento de Cervantes, 3. El error y la armonía como temas literarios. I: Américo Castro: Obra reunida, vol. I. Madrid, 2002 [1925], s. I3I.

6. "nadie puede prometerse en este mundo más horas de vida de las que Dios quisiere darle, porque la muerte es sorda, y cuando llega a llamar a las puertas de nuestra vida, siempre va de prisa, y no la harán detener ni ruegos, ni fuerzas, ni cetros, ni mitras, según es pública voz y fama, y según nos lo dicen por esos púlpitos." (kap. VII, bd. II).

7. me parece duro caso hacer esclavos a los que Dios y naturaleza hizo libres" (kap. XXII, bd. I)

8. Américo Castro: El pensamiento de Cervantes, 4. La naturaleza como principio divino e inmanente. I: Américo Castro: Obra reunida, vol. I. Madrid, 2002 [1925].

9. I artiklen "Sækulariseret alviden" i: Passage, nr. 47, 2003, Det encyklopædiske.

Io. Márquez Villanueva, Francisco: "El caso del averroísmo popular español (hacia «La Celestina»)". I: Averroes dialogado y otros momentos literarios $y$ sociales de la interacción cristiano-musulmana en España e Italia. Ed. André Stoll. Kassel, 1998 .

II. Márquez Villanueva, Francisco: "In Lingua Tholetana". I: La escuela de traductores de Toledo. Toledo 1996.

I2. Riera Palmero, Juan: "El influjo greco-árabe en la medicina latina medieval". I: Vida cotidiana en la España medieval. Aguilar de Campoo, Madrid, I998.

13. Ernest Renan: Averroès et l'averrö̈sme, 1852, Essai historique. I: Guvres Complètes de Ernest Renan, ed. Henriette Psichari, t. III. Paris, I947-6I, s. I23.

14. Eckhard Keßler: "Metaphysics or Empirical Science?", I: Renaissance Readings of the Corpus Aristotelicum. ed. Marianne Pade, København, $200 \mathrm{I}$.

Is.Jamal Al-Din Al-'Alawi: "The Philosophy of Ibn Rushd”, I: The Legacy of Muslim Spain. ed. Salma Khadra 
Jayyusi. Leiden, 1992.

I6. Averroes er ikke ene om at hævde sjælens eller intellektets dødelighed. Det samme gjorde en tidligere stor Aristoteles-kommentator Alexander fra Aphrodisias (o. 200, vor tid). Olaf Pluta: "The Transformations of Alexander of Aphrodisias' Interpretation of Aristotle's Theory of the Soul", I: Renaissance Readings of the Corpus Aristotelicum, ed. Marianne Pade, København, 200I. s. I49. Alexanders De anima blev oversat til arabisk i 9ro og var tilgængelig for Averroes (Ibn Rushd), der citerer fra den. I7. Miguel Cruz Hernández: "Islamic Thought in the Iberian Peninsula", I: The Legacy of Muslim Spain, ed. Salma Khadra Jayyusi, Leiden, 1992.

I8. Lasker, Daniel J.: "Averroistic Trends in Jewish-Christian Polemics in the Late Middle Ages", Speculum, Vol. 55,2 , 1980.

I9. "Paréceme, oh Anselmo, que tienes tú ahora el ingenio como el que siempre tienen los moros, a los cuales no se les puede dar a entender el error de su secta con las acotaciones de la Santa Escritura, ni con razones que consistan en especulación del entendimiento, ni que vayan fundadas en artículos de fe, sino que les han de traer ejemplos palpables, fáciles, inteligibles, demostrativos, indubitables, con demostraciones matemáticas, que no se pueden negar, como cuando dicen: «Si de dos partes »iguales quitamos partes iguales, las que "quedan también son iguales.» Y cuando esto no entiendan de palabra, como en efecto no lo entienden, háseles de mostrar con las manos $\mathrm{y}$ ponérselo delante de los ojos, y aún con todo esto no basta nadie con ellos a persuadirles las verdades de mi sacra religión. Y este mismo término y modo me convendrá usar contigo, porque el deseo que en ti ha nacido va tan descaminado y tan fuera de todo aquello que tenga sombra de razonable, que me parece que ha de ser tiempo gastado el que ocupare en darte a entender tu simplicidad, que por ahora no le quiero dar otro nombre, y aun estoy por dejarte en tu desatino, en pena de tu mal deseo; mas no me deja usar de este rigor la amistad que te tengo, la cual no consiente que te deje puesto en tan manifiesto peligro de perderte (kap. XXXIII, bd. I).

20. Det passer godt med, at Américo Castro betragter
Cervantes som hykler, der hylder kontrareformens dobbelte sandhed, hvor man både holder sig til troen og til fornuften uden at kere sig om, at de to holdninger er uforenelige: "Decíamos que el católico inquieto tomó ya el camino del libertinismo ateísta (en España sin manifestación perceptible), o el más felxible y dificil de la «doble verdadı: verdad de fe, verdad de razón (de orígen escolástico, pero con nuevo sentido desde Pomponazzi), sin detenerse a poner de relieve la incompatibilidad de una y otra." Américo Castro: "El pensamiento de Cervantes", 6. Ideas religiosas. I: Américo Castro: Obra reunida, vol. I. Madrid, 2002 [1925], s. 232.

2I. Todas éstas, y otras grandes y diferentes hazañas son, fueron y serán obras de la fama que los mortales desean como premios y parte de la inmortalidad que sus famosos hechos merecen, puesto que los cristianos, católicos y andantes caballeros más hemos de atender a la gloria de los siglos venideros, que es eterna en las regiones etéreas y celestes, que a la vanidad de la fama que en este presente y acabable siglo se alcanza; la cual fama, por mucho que dure, en fin se ha de acabar con el mismo mundo, que tiene su fin señalado. (kap. VIII, bd. II).

22.Iagttagelsen har jeg fra Edward T. Riley: "Cómo se termina un relato: los finales de las novelas ejemplares", I: Actas del X Congreso de la Asociación Internacional de Hispanistas, ed. Antonio Vilanova, Barcelona 1989. "Y con esto, se fueron."

23. Afslutningen på prologen til Persiles lyder: “Tiempo vendrá, quizá, donde, anudando este roto hilo, diga lo-que aquí me falta y lo que sé convenía.

¡Adiós, gracias; adiós, donaires; adiós, regocijados amigos! Que yo me voy muriendo y deseando veros presto contentos en la otra vida." Miguel de Cervantes: Los trabajos de Persiles y Sigismunda, s. II4.

24. “Ayer me dieron la estremaunción y hoy escribo ésta, el tiempo es breve, las ansias crecen, las esperanzas menguan y, con todo esto, llevo la vida sobre el deseo que tengo de vivir. [...] Si, a dicha, por buena ventura mía (que ya no sería ventura, sino milagro), me diese el cielo vida [...]" Miguel de Cervantes: Los trabajos de Persiles y Sigismunda, s. I08-9. 